\title{
The Effect Of Social Media Marketing On Purchase Decisions With Brand Awareness As An Intervening Variables In Praketa Coffee Shop Purwokerto
}

\author{
Ilham Fajri', Mochamad Whilky Rizkyanfi², Rizma Ismaya ${ }^{2}$ \\ ${ }^{1}$ Akademi Pariwisata NHI, Dr. Setiabudi No. 186 Street, Bandung 40141, Indonesia \\ ${ }^{2}$ Universitas Pendidikan Indonesia, Dr. Setiabudhi No. 229 Street, Bandung 40154, Indonesia \\ *Corresponding Author. E-mail: ilham@akparnhi.ac.id(Ilham Fajri)
}

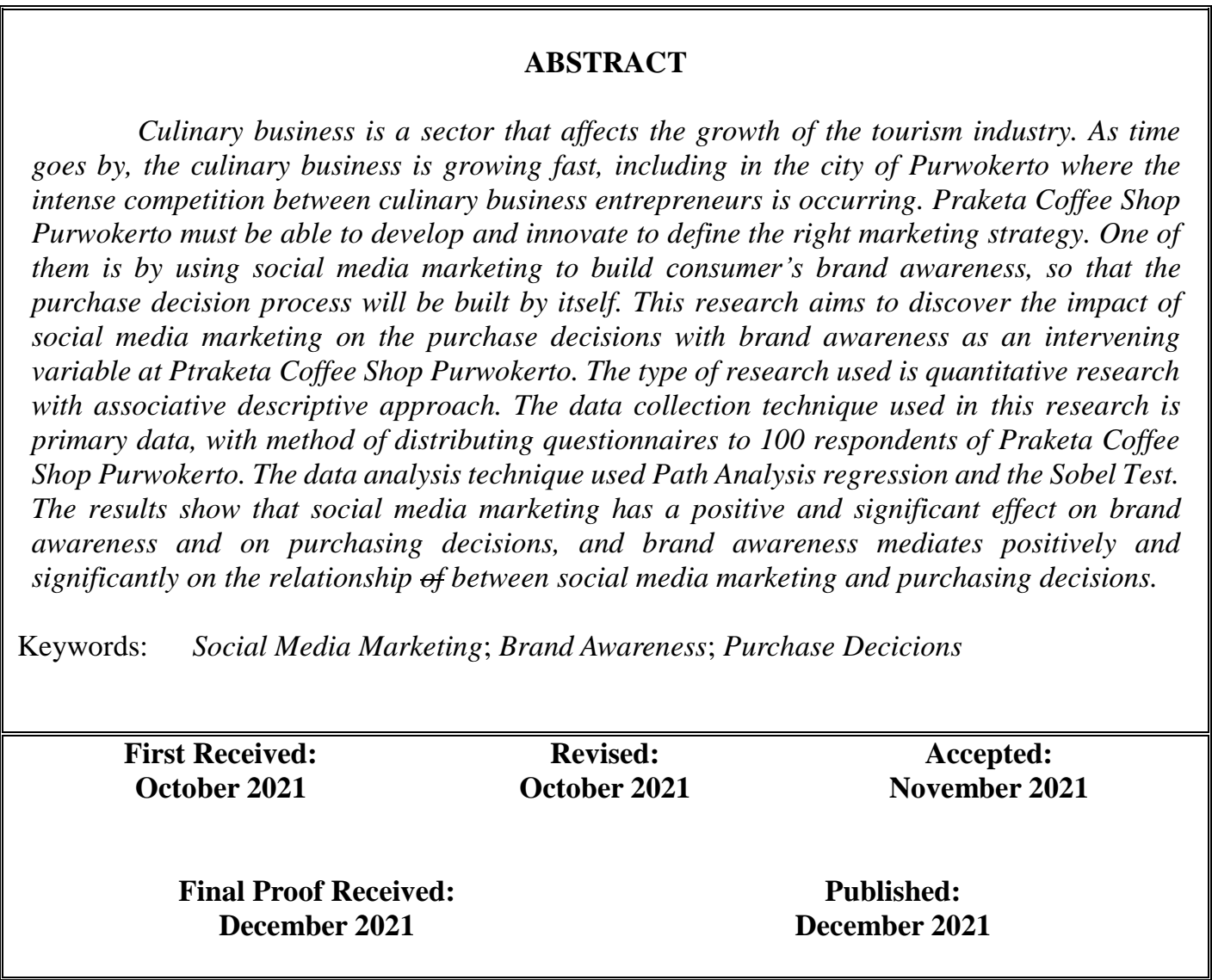




\section{Introduction}

Internet technology is currently an important need for humans. In addition to being a means of communication, the internet has many uses such as a means of publication, marketing strategies, and exchanging information. Internet users in Indonesia in early 2021 reached 202.6 million or $73.7 \%$ of the total population of 274.9 million people. According to that data, about 195.3 million people or $94.6 \%$ of Indonesian people use the Internet via mobile phones. The increase of Internet users impacts on human lifestyle, which means that companies must be able to compete and innovate in introducing products or services, so that they can be welcomed (Kuspriyono \& Nurelasari, 2018).

Among other tourism sectors, the culinary business is a sector that is quite large in using internet technology as a marketing strategy. Praketa Coffee Shop Purwokerto as one of the culinary businesses, implements its marketing strategy through social media. People use social media because it is easy to access and have features that are very useful to human life. The internet has access that can be used anywhere and anytime, and makes it easier for people getting up-to-date information about the product or service they need (Oktaviani \& Rustandi, 2018).

Many business people think that the use of social media marketing can provide operational benefits, because it does not cost too much for promotion and is more efficient. The impact of product sales increases when many consumers visit the company's website and find out about the products offered. The purpose of this marketing is to place a brand into the top of the consumers mind so that when they need a product, consumers directly remember a brand. Marketing using social media must be creative and interesting so that it can form a brand awareness (Upadana \& Pramudana, 2020). This is very effective in introducing a business or business brand to consumers widely and can make the brand in the minds of consumers in making it a brand reference when they want to make a purchase.

Praketa Coffee Shop has been around for a long time and has become one of the most well-known brands in Purwokerto. In its development, Praketa Coffee Shop has established quite good on brand awareness through their social media marketing. According to the owner of the Praketa Coffee Shop, it appears that brand or some new coffee shops are likely to cause problems on the brand awareness consumers of the Praketa Coffee Shop brand, because there is an opportunity for consumers to try every other brand, even maybe the consumer can switch to a coffee shop.

To find out the phenomenon of the influence of social media marketing on the formation of brand awareness and purchasing decisions, researchers conducted a pre-survey by distributing online questionnaires to 34 respondents who had made purchases at Praketa Coffee Shop Purwokerto.

Table 1. Pre-survey Research on Praketa Coffee Shop Purwokerto

\begin{tabular}{|c|l|c|c|}
\hline No & \multicolumn{1}{|c|}{ Statement } & \multicolumn{2}{|c|}{$\begin{array}{c}\text { Number of } \\
\text { Respondents }\end{array}$} \\
\cline { 3 - 4 } & & Yes & No \\
\hline 1 & $\begin{array}{l}\text { Praketa Coffee Shop establishing communication } \\
\text { with customers through social media. }\end{array}$ & 28 & 6 \\
\hline 2 & $\begin{array}{l}\text { Praketa Coffee Shop using social media as a medium } \\
\text { to receive criticism and suggestions. }\end{array}$ & 25 & 9 \\
\hline 3 & $\begin{array}{l}\text { Trademark or brand of Praketa Coffee Shop sounds } \\
\text { ear-catching. }\end{array}$ & 28 & 6 \\
\hline 4 & $\begin{array}{l}\text { When asked about the coffee product or a place to } \\
\text { just hang out, a brand that always comes to your } \\
\text { mind is Praketa Coffee Shop brand. }\end{array}$ & 14 & 20 \\
\hline 5 & $\begin{array}{l}\text { I prioritize to buy products or to visit Praketa } \\
\text { Coffee Shop in addition to other products or cafes }\end{array}$ & 14 & 20 \\
\hline 6 & $\begin{array}{l}\text { I am willing to sacrifice time or price for products } \\
\text { or to visit Praketa Coffee Shop. }\end{array}$ & 28 & 6 \\
Source: Data Processed by Researches, 2021 & \\
\hline
\end{tabular}

The results of the pre-survey in Table 1. which have been conducted on 34 respondents, show the phenomena of social media marketing, brand awareness, and purchasing decisions. This can be seen from statement number 1, "Praketa Coffee Shop builds communication with its consumers through social media", 28 respondents answered yes and 9 respondents answered no. This can be seen from statement number 3 which states that the Praketa Coffee Shop brand sounds familiar and well-known 
among consumers, which proves the use of social media as a marketing medium by Praketa Coffee Shop. The statements include, "Trademark or brand of Praketa Coffee Shop sounds ear-catching.", 28 respondents answered yes and 6 respondents answered no. However, for the next statement in number 4, "When asked about coffee products or a place to just hangout, the brand that always comes to your mind is the Praketa Coffee Shop brand" 14 respondents answered yes and 20 respondents answered no, and for statement number 5 "I prioritize buying products or visiting Praketa Coffee Shop than other products or cafes." 14 respondents were willing to prioritize Praketa Coffee Shop, while 20 respondents said they were not. This states that consumer awareness of the Praketa Coffee Shop brand only reaches the level of brand recognition described in statement number 4, consumers do not make Praketa Coffee shop as the brand that will be chosen the most in their minds (top of mind). Regarding the statement in number 5, that consumers do not prioritize to buy Praketa Coffee Shop products, it reduces the purchase decisions that will occur.

Based on this analysis, we can see that social media marketing can influence the formation of brand awareness and purchase decisions. Research conducted by Upadana \& Pramudana (2020) states that social media marketing plays a role in shaping brand awareness to determine a purchase decision. Social media marketing must be carried out with innovative and interesting activities to build brand awareness consumer, so that consumers have high confidence in the product and consumers can decide on the purchase decision (Upadana \& Pramudana, 2020).

Based on the background explained, the use of social media in marketing activities is very important and is related to brand awareness and consumer purchasing decisions. Therefore, the author is very interested in knowing the phenomenon of the influence of social media marketing on purchasing decisions mediated by brand awareness at Praketa Coffee Shop Purwokerto.

Based on the description of the theory and, it can be concluded several hypotheses in this study, namely as follows:

1) H1: Social media marketing has a positive and significant effect on brand awareness of Praketa Coffee Shop Purwokerto.

2) H2: Social Media Marketing has a positive and significant effect on the purchase decision in Praketa Coffee Shop Purwokerto.

3) H3: Brand awareness has a positive and significant effect on Praketa Coffee Shop Purwokerto purchase decision.

4) H4: Brand awareness mediates positively and significantly on the relationship between Social Media Marketing and Praketa Coffee Shop Purwokerto purchase decision.

The theoretical model of thought in this study is based on a description of the theory and previous research, as follows:

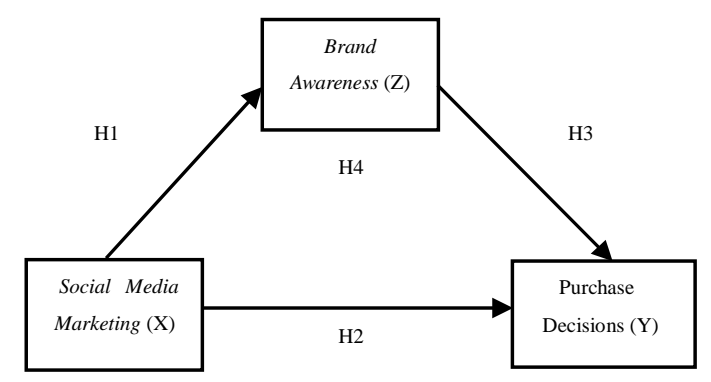

Figure 1. Theoritical Model

\section{Literature Review}

\subsection{Social Media Marketing}

According to Kuspriyono \& Nurelasari (2018), social media is a way to share information in the form of text, audio, or video used by consumers or companies to interact or communicate that can be done at a distance. In social media marketing activities, it is used to facilitate the promotion process to consumers.

Promotional activities carried out by a company using social media have a greater increase than non-social media promotions 
(Zahid, 2014).

Social media marketing platforms have the ability to expand brand recognition to people globally so that consumers can get more than ever before (Poturak \& Softić, 2019).

Social media marketing uses social media as a marketing channel so that we can use the characteristics of social media as a measurement dimension. The following are social media marketing indicators that have been adapted to this research according to Sutariningsih (2021) and Godey (2016), namely:

1) Entertainment

Entertainment is an experience that brings pleasure or interest to the use of social media.

2) Interaction

Interaction is communication between companies and consumers, such as sharing information, exchanging opinions, views, suggestions, criticisms, or praise about a product or brand provided by the company.

3) Trendiness

Trendiness or modern conditions at this time that require social media to provide the latest topics or news to consumers. Trendiness plays a role in providing the latest content, such as product information, promotions or discounts, or other services provided by the company.

4) Customization

Customization in social media has a role in providing a search for information and services that are tailored and provided based on consumer demand or needs.

5) Word of Mouth

Word of mouth is useful in shaping communication between consumers to other consumers. In this case word of mouth is the consumer's desire to share information about a product or brand to another consumer through direct or redistributive conversation using the consumer's own social media.

\subsection{Brand Awareness}

Brand awareness or brand awareness is defined as the ability of consumers to identify a brand when given to them under different conditions. Brand awareness can be enhanced when someone can see, know, and remember that brand on their mind. Therefore, companies are making efforts to raise brand awareness by designing logos, symbols, characters, packages, advertisements or promotions with slogans that can shape and raise consumer awareness of a brand (Yapa, 2017).

According to Herdana (2015), brand awareness is the ability of consumers to remember and recognize a brand or product in their own minds. Raising awareness of a brand is one of the ways to introduce and develop a brand to a wider market.

Consumers will buy a product or use a service based on a brand they know and trust. This is important for every company to create brand awareness because it can allow a brand to be chosen or purchased because it first appears in the minds of consumers (Sutariningsih, 2021).

Brand awareness in this study is the ability of consumers to remember a brand or advertisement through spontaneous circumstances or after being stimulated by keywords. Brand awareness indicators according to Upadana \& Pramudana (2020) and have been adapted to this research are:

1) Brand Knowledge

Consumers can remember a brand well and sound familiar to consumers. This is caused by how often consumers make purchases of the brand.

2) Well-known

Brands can be known by all circles and have the ability to become the main topic if consumers are in need or need a brand.

3) Distinguishable

Brands that can be distinguished from other brands, both from the taste and characteristics of the brand. On the other hand, brands have characteristics that can make consumers feel more special when they buy the brand.

\subsection{Purchase Decisions}

Consumer decision to make the purchase of a product or service begins with awareness of the need or desire. According to Sara (2009) purchasing decisions are a 
decision-making process that someone makes through an evaluation process to choose an alternative.

The purchase process took place long before the actual purchase and had (Ernawan et al., 2018)

According to Adhawiyah (2019) there are two factors that are sufficiently influential between consumer intentions to buy and purchasing decisions. These two factors, inter alia, the attitude that emerges from others and the situation or the situation that can change.

The decision making process is important to make because it can help consumers dig information about a set of brands or products, evaluate brands or products even choose between alternatives and ultimately make good and customer-friendly decisions (Siali et al., 2016).

Purchase decision indicators according to Upadana \& Pramudana (2020) are when consumers decide to make a purchase of a product influenced by four indicators namely:

\section{Decision to choose}

Consumers have the opportunity to choose a product or brand in every purchase they will make. This decision arises because consumers need the product or service.

\section{Priority}

Consumers will prioritize buying a particular product or brand compared to others. This happens because consumers have trusted the product or brand.

\section{Awareness of sacrifice}

Consumers are willing to sacrifice for a particular product or brand, both in time, cost, and effort to get it.

4. Like the product

Consumers feel happy after buying a certain product or brand, because it is in accordance with what they want.

\section{Materials and Methods}

This study uses a quantitative descriptive method with an associative approach. Associative research aims to explain the effect of social media marketing variables on purchasing decisions through brand awareness. This research was conducted at Praketa Coffee Shop Purwokerto with the object of research, namely, social media marketing as an independent variable $(\mathrm{X})$, brand awareness as an intervening variable (mediation) $(\mathrm{Z})$, and purchasing decisions as the dependent variable $(\mathrm{Y})$.

In data collection, this study uses a non-probability sampling method with purposive sampling technique, which is a sampling carried out with criteria set by researchers, such as consumers who have visited Praketa Coffee Shop and are 18 years old and over. Data was collected by distributing online questionnaires or questionnaires using Google Form to 100 respondents who met the criteria according to the research using Likert scale measurements. The data analysis technique used descriptive analysis technique, classical assumption test, path analysis regression, and Sobel test.

\section{Results and Discussion}

Praketa Coffee Shop is a café that was established in 2015. This cafe is located in the city of Purwokerto, precisely on Jl. HR Boenyamin No. 129 Purwokerto which is a strategic place because it is located around campus and the city center. According to the cafe owner Indra Purnama Aji, Praketa comes from Sanskrit which means "knowledge or point of view". At first, this cafe only had a limited menu, such as single origin black coffee with manual brewing techniques that characterize this café. As for the food menu, there is only a cake menu, such as cheese cake and oreo cake. Over time, Praketa Coffee is increasingly developing and expanding its menu so that consumers have more choices when visiting. In addition to a diverse menu, the concept of a minimalist-style building with a touch of wood in every corner of the café room gives visitors a comfortable and calm impression.

The questionnaire consists of three parts, namely statements regarding the 
respondent's criteria, respondent's experience and respondents' responses to the variables of social media marketing, brand awareness, and purchasing decisions at Praketa Coffee Shop Purwokerto. In filling out the questionnaire, respondents were asked to give the symbol (x) to each item of the statement. Each statement item consists of 5 response scores, namely, Strongly Agree (5), Agree (4), Neutral (3), Disagree (2), Strongly Disagree (1).

\subsection{Characteristics of Respondents}

Characteristics of respondents are presented in the following data:

Table 2. Characteristics of Respondents by Sex

\begin{tabular}{|c|c|c|}
\hline Sex & $\begin{array}{c}\text { Frequ } \\
\text { ency }\end{array}$ & $\begin{array}{c}\text { Percentage } \\
(\mathbf{\%})\end{array}$ \\
\hline Male & 54 & $54 \%$ \\
\hline Female & 46 & $46 \%$ \\
\hline Total & $\mathbf{1 0 0}$ & $\mathbf{1 0 0 \%}$ \\
\hline Source: Data Processed by Researches,2021
\end{tabular}

Based on table 2, it can be seen that male respondents were the most frequent visitors (54\%) and female respondents were 46 people $(46 \%)$.

Table 3. Characteristics of

Respondents Based on Age

\begin{tabular}{|c|c|c|}
\hline Age & Frequency & $\begin{array}{l}\text { Percent } \\
\text { age }(\%)\end{array}$ \\
\hline $18-20$ years & 31 & $31 \%$ \\
\hline $21-25$ years & 57 & $57 \%$ \\
\hline $25-30$ years & 11 & $11 \%$ \\
\hline$>30$ years & 1 & $1 \%$ \\
\hline Total & 100 & $100 \%$ \\
\hline
\end{tabular}

Based on table 3, it can be seen that respondents who visited Praketa Coffee Shop Purwokerto aged 21-25 years were the most frequent visitors namely 57 people or with a percentage of $57 \%$. In addition, for visitors aged 18-20 years, there were 31 people or $31 \%$, then for those

aged 25-30 years there were 11 people or $11 \%$, and visitors aged $>30$ years were only 1 person or $1 \%$. This shows that most of the visitors are young people.

Table 4. Characteristics of Respondents Based on Occupation

\begin{tabular}{|c|c|c|}
\hline Occupation & Frequency & $\begin{array}{c}\text { Percentage } \\
(\%)\end{array}$ \\
\hline Student & 67 & $67 \%$ \\
\hline Employee & 17 & $17 \%$ \\
\hline Entrepreneur & 7 & $7 \%$ \\
\hline $\begin{array}{c}\text { Private } \\
\text { Employee }\end{array}$ & 3 & $3 \%$ \\
\hline $\begin{array}{c}\text { Fresh } \\
\text { Graduate }\end{array}$ & 1 & $1 \%$ \\
\hline Satpol PP & 1 & $1 \%$ \\
\hline Civil servant & 1 & $1 \%$ \\
\hline Barista & 1 & $1 \%$ \\
\hline Freelance & 1 & $1 \%$ \\
\hline Housewife & 1 & $1 \%$ \\
\hline Total & 100 & $100 \%$ \\
\hline
\end{tabular}

Based on table 4. it can be seen that from 100 respondents according to job criteria, there are 67 or $67 \%$ of people in the student category as the most frequent visitors to Praketa Coffee Shop Purwokerto. In addition, there are 17 respondents who work as employees or $17 \%, 7$ people or $7 \%$ of respondents are entrepreneurs, 3 people or $3 \%$ of respondents who work as private employees, then categories that are not listed in the questionnaire options such as fresh graduates, Satpol PP, Civil servant, Barista, Freelance, and housewives each as many as 1 person or $1 \%$.

Table 5. Characteristics of Respondents Based on Monthly Income

\begin{tabular}{|c|c|c|}
\hline Income & Frequency & $\begin{array}{c}\text { Pecentage } \\
(\mathbf{\%})\end{array}$ \\
\hline$<\mathrm{Rp} 1.000 .000$ & 41 & $41 \%$ \\
\hline $\mathrm{Rp} 1.000 .000-\mathrm{Rp}$ & 38 & $38 \%$ \\
2.500 .000 & & $11 \%$ \\
\hline $\mathrm{Rp} 2.500 .000-\mathrm{Rp}$ & 11 & $10 \%$ \\
\hline 5.000 .000 & & $\mathbf{1 0 0 \%}$ \\
\hline$<\mathrm{Rp} \mathrm{5.000.000}$ & 10 & $\mathbf{1 0 0}$ \\
\hline Total & Source: Data Processed by Researches,2021
\end{tabular}

Based on table 5. it can be seen that respondents who often visit Praketa Coffee Shop Puwokerto by looking at the information on monthly income, which is $<$ Rp 1,000,000, get the highest number of 41 people or with a percentage of $41 \%$. Then respondents with an income of 1,000,000 Rp 2,500,000 as many as 38 people or $38 \%$, respondents with an income of $\mathrm{Rp}$ 2,500,000 - Rp. 5,000,000 as many as 11 
people or $11 \%$ and respondents with income $<\operatorname{Rp} 5,000,000$ as many as 10 people or $10 \%$.

\subsection{Respondent experience}

The following is a description of the results of the respondent experience in this study:

Table 6. Respondents' Initial Knowledge

Experience of Praketa Coffee Shop

\begin{tabular}{|c|c|c|}
\hline & Frequency & $\begin{array}{c}\text { Percentage } \\
(\mathbf{\%})\end{array}$ \\
\hline Initial Knowledge & 60 & $60 \%$ \\
\hline Family/Friends & 31 & $31 \%$ \\
\hline Social Media & - & - \\
\hline Print Media & 9 & $9 \%$ \\
\hline Random view & $\mathbf{1 0 0}$ & $\mathbf{1 0 0 \%}$ \\
\hline Total & \multicolumn{3}{|l}{}
\end{tabular}

The shows that most respondents know where Praketa Coffee Shop Purwokerto is from information from their family or close friends, with the number of respondents of 60 percent. Then respondents who know through social media as many as 31 or $31 \%$, respondents who randomly see as many as 9 or $9 \%$, and $0 \%$ or no respondents who know Praketa Coffee Shop Purwokerto through print media. Based on that table, it can be summarised that from 100 respondents, as most of them know the coffee shop through information from someone or word of mouth and social media.

Table 7. Respondent's Experience Based on Frequency of Visiting Praketa Coffee Shop

\begin{tabular}{|c|c|c|}
\hline Frequency of Visiting & Frequency & Percentage \\
\hline 1 time & 14 & $14 \%$ \\
\hline $2-5$ times & 44 & $44 \%$ \\
\hline$>5$ times & 42 & $42 \%$ \\
\hline Total & $\mathbf{1 0 0}$ & $\mathbf{1 0 0 \%}$ \\
\hline Source: Data Processed by Researches, 2021
\end{tabular}

The results of data processing can be seen that respondents often make visits with a frequency of 2-5 times as many as 44 people or with a percentage of $44 \%$. In addition, for the frequency of visits $>5$ times, 42 people or a percentage of $42 \%$ and 14 or $14 \%$ of people who visit Praketa Coffee Shop 1 time.

Tabel 8. Respondent's Experience Based on Purpose of Visiting Praketa Coffee Shop

\begin{tabular}{|c|c|c|}
\hline Purpose of Visiting & Frequency & Percentage (\%) \\
\hline Eat/Drink & 43 & $43 \%$ \\
\hline Doing Assignment & 19 & $19 \%$ \\
\hline Hangout & 30 & $30 \%$ \\
\hline Others & 8 & $8 \%$ \\
\hline Total & $\mathbf{1 0 0}$ & $\mathbf{1 0 0 \%}$ \\
\hline
\end{tabular}

The data above shows that most respondents visit the Praketa Coffee Shop to eat or drink $(43 \%), 19 \%$ respondents visit the coffee shop to do assignments, $30 \%$ to hangout or gathering, and $8 \%$ to do activities outside the category. Therefore, it can be concluded that Praketa Coffee Shop Purwokerto is a place that is often visited for eating, drinking, or just gathering together.

\subsection{Descriptive Analysis Results of Social Media Marketing Variable}

The following is a explanation of the results of the descriptive analysis of each item of the research statement:

Tabel 9. Responses to Social Media Marketing

\begin{tabular}{|c|c|c|c|c|}
\hline No & Statement & $\begin{array}{l}\text { Total } \\
\text { Score }\end{array}$ & Average & $\begin{array}{r}\text { Categ } \\
\text { ory }\end{array}$ \\
\hline 1 & $\begin{array}{l}\text { Praketa Coffee's social media provides } \\
\text { interesting image posts. }\end{array}$ & 413 & $82,6 \%$ & Good \\
\hline 2 & $\begin{array}{l}\text { Praketa Coffee social media provides } \\
\text { interesting video posts. }\end{array}$ & 392 & $78,4 \%$ & Good \\
\hline 3 & $\begin{array}{l}\text { Praketa Coffee's social media provides } \\
\text { clear information. }\end{array}$ & 426 & $85,2 \%$ & $\begin{array}{c}\text { Very } \\
\text { Good }\end{array}$ \\
\hline 4 & $\begin{array}{l}\text { Praketa Coffee's social media provides facilities } \\
\text { for the exchange of opinions, such as opinions, } \\
\text { suggestions, and criticisms. }\end{array}$ & 400 & $80 \%$ & Good \\
\hline 5 & $\begin{array}{l}\text { Praketa Coffee's social media provides } \\
\text { interesting content according to today's } \\
\text { conditions. }\end{array}$ & 418 & $83,6 \%$ & Good \\
\hline 6 & $\begin{array}{l}\text { Praketa Coffee's social media uses } \\
\text { easy-to-understand language for each } \\
\text { content or segment. }\end{array}$ & 435 & $87 \%$ & $\begin{array}{c}\text { Very } \\
\text { Good }\end{array}$ \\
\hline 7 & $\begin{array}{l}\text { Praketa Coffee 's social media provides } \\
\text { information search and special services for } \\
\text { Praketa Coffee } \\
\text { Consumers }\end{array}$ & 398 & $79,6 \%$ & Good \\
\hline 8 & $\begin{array}{l}\text { Praketa Coffe's social media considering } \\
\text { suggestions from consumers to be used as } \\
\text { material for posting or content on social } \\
\text { media. }\end{array}$ & 402 & $80,4 \%$ & $\begin{array}{l}\text { Very } \\
\text { Good }\end{array}$ \\
\hline 9 & $\begin{array}{l}\text { I am willing to share information } \\
\text { about Praketa Coffee's brands, products and } \\
\text { services to my friends }\end{array}$ & 414 & $83,8 \%$ & Good \\
\hline 10 & $\begin{array}{l}\text { I am willing to upload content or } \\
\text { information that I get from } \\
\text { Praketa Coffee's social media on my social } \\
\text { media. }\end{array}$ & 397 & $79,4 \%$ & Good \\
\hline \multicolumn{3}{|c|}{ Total Rate } & 409,5 & \multirow[t]{2}{*}{ Baik } \\
\hline \multicolumn{3}{|c|}{ Percentage } & $81,9 \%$ & \\
\hline
\end{tabular}

Based on table 9., it is known that the total average (mean) score obtained from the social media marketing variable is 409.5 out of a total score of 500 or $81.9 \%$ in percentage form. So overall respondents' responses to social media marketing variables at Praketa Coffee Shop Purwokerto are categorized into good categories.

Based on the results of the descriptive analysis of social media marketing variables 
in table 9, it is known that the indicator with the highest score is found in two indicators, namely, X.3 with a score of 426 or $85.2 \%$ and X.6 indicator with a score of 435 or $87 \%$, a score This falls into the very good category. This shows that Praketa Coffee Shop always provides clear information and easy-to-understand language in each content or segment.

\section{Description of Brand Awareness Variable}

The following is a description of the results of the descriptive analysis of each item of the research statement:

Table 10. Responses on Brand Awareness

\begin{tabular}{|c|c|c|c|c|}
\hline No & Statement & $\begin{array}{l}\text { Total } \\
\text { Scor }\end{array}$ & $\begin{array}{c}\text { Avera } \\
\text { ge }\end{array}$ & $\begin{array}{c}\text { Categor } \\
\mathrm{y}\end{array}$ \\
\hline 1 & $\begin{array}{l}\text { I realized the existence of Praketa Coffee } \\
\text { because the shop was easy to find. }\end{array}$ & 410 & $82 \%$ & Good \\
\hline 2 & $\begin{array}{l}\text { I recognized Praketa Coffee just by looking at } \\
\text { their products. }\end{array}$ & 364 & $72,8 \%$ & Good \\
\hline 3 & $\begin{array}{l}\text { I remember Praketa Coffee as a coffee shop } \\
\text { with a variety of products and services. }\end{array}$ & 427 & $85,2 \%$ & $\begin{array}{l}\text { Verry } \\
\text { Good }\end{array}$ \\
\hline 4 & $\begin{array}{l}\text { Praketa Coffee is the first brand that comes to } \\
\text { my mind when I want to drink coffee or just } \\
\text { hangout at a coffee shop. }\end{array}$ & 351 & $\begin{array}{c}70,2 \% \\
\%\end{array}$ & Good \\
\hline 5 & $\begin{array}{l}\text { Praketa Coffee is a well-known brand in } \\
\text { Purwokerto. }\end{array}$ & 412 & $82,4 \%$ & Good \\
\hline 6 & $\begin{array}{l}\text { I can distinguish Praketa Coffee brand } \\
\text { products from other brands. }\end{array}$ & 375 & $75 \%$ & Good \\
\hline 7 & $\begin{array}{l}\text { Praketa Coffee brand products have } \\
\text { different characteristics from other brands. }\end{array}$ & 377 & $75,4 \%$ & Good \\
\hline 8 & $\begin{array}{l}\text { I feel special or proud when I } \\
\text { buy Praketa Coffee brand products. }\end{array}$ & 375 & $75 \%$ & Good \\
\hline \multicolumn{3}{|c|}{ Average Value in Total Rate } & 392 & \multirow[t]{2}{*}{ Good } \\
\hline \multicolumn{3}{|c|}{ Percentage } & $\begin{array}{c}78,4 \\
\%\end{array}$ & \\
\hline
\end{tabular}

Based on table 10, it can be seen that the total overall average (mean) score obtained from the brand awareness variable is 392 or $78.4 \%$ in percentage terms. Overall, according to this score, respondents' responses to the brand awareness variable at Praketa Coffee Shop Purwokerto are categorized into good categories.

Based on the results of the descriptive analysis of the brand awareness variable in table 10, the indicator that gets the largest score is the statement item Z.3 with a score of 427 or $85.4 \%$, this score is included in the very good category. This indicates that Praketa Coffee Shop Purwokerto always provides good and varied products, services, so that respondents are able to remember the Praketa Coffee Shop brand well.

\section{Description of Purchase Decision Variable}

The following is a description of the results of the descriptive analysis of each item of the research statement:

Tabel 11. Responses for Purchase Decision

\begin{tabular}{|c|c|c|c|c|}
\hline No & Statement & $\begin{array}{l}\text { Total } \\
\text { Scor }\end{array}$ & Average & $\begin{array}{c}\text { Categ } \\
\text { ory }\end{array}$ \\
\hline 1 & $\begin{array}{l}\text { I decided to choose Praketa Coffee as a place } \\
\text { to hang out and drink coffee, from other } \\
\text { coffee shops. }\end{array}$ & 383 & $76,6 \%$ & Good \\
\hline 2 & $\begin{array}{l}\text { I decided to choose Praketa Coffee as a place } \\
\text { to hang out and drink coffee because of my } \\
\text { own desire. }\end{array}$ & 409 & $81,1 \%$ & Good \\
\hline 3 & $\begin{array}{l}\text { I decided to choose Praketa Coffee as a place } \\
\text { to hang out and drink coffee because I saw } \\
\text { other people's experiences. }\end{array}$ & 355 & $71 \%$ & Good \\
\hline 4 & $\begin{array}{l}\text { I prioritize buying Praketa Coffee products } \\
\text { over other products }\end{array}$ & 348 & $69,6 \%$ & Good \\
\hline 5 & $\begin{array}{l}\text { I prioritize buying Praketa Coffee products } \\
\text { because of the quality of the products. }\end{array}$ & 384 & $76,8 \%$ & Good \\
\hline 6 & $\begin{array}{l}\text { I am willing to sacrifice time and money to } \\
\text { buy Praketa Coffee products. }\end{array}$ & 351 & $70,2 \%$ & Good \\
\hline 7 & $\begin{array}{l}\text { I am willing to always be loyal to Praketa } \\
\text { Coffee. }\end{array}$ & 348 & $69,6 \%$ & Good \\
\hline 8 & $\begin{array}{l}\text { I feel happy or satisfied after deciding to buy } \\
\text { Praketa Coffee brand products. }\end{array}$ & 391 & $78,2 \%$ & Good \\
\hline 9 & $\begin{array}{l}\text { I am willing to make repeated purchases at } \\
\text { Praketa Coffee. }\end{array}$ & 390 & $78 \%$ & Good \\
\hline $\begin{array}{l}1 \\
0\end{array}$ & $\begin{array}{l}\text { I will recommend Praketa Coffee to my } \\
\text { friends. }\end{array}$ & 419 & $83,8 \%$ & Good \\
\hline \multicolumn{3}{|c|}{ Average Value in Total } & 377,8 & \multirow[t]{2}{*}{ Good } \\
\hline & Percentage & & $75,6 \%$ & \\
\hline
\end{tabular}

Based on table 11. it can be seen that the total overall average (mean) score obtained from the purchasing decision variable is 377.8 or $75.6 \%$ in percentage form. Overall, according to this score, respondents' responses to the purchasing decision variables at Praketa Coffee Shop Purwokerto are categorized into good categories.

Based on the results of the descriptive analysis of the purchasing decision variables in table 11, the indicator that gets the highest score is the statement item Y.10 with a score of 419 or $83.8 \%$, this score is included in the good category. This indicates that Praketa Coffee Shop Purwokerto always gives good trust so that consumers are able to make decisions by recommending Praketa Coffee Shop to other consumers.

\subsection{Validity Test}

The following data is a validity test result for each variable: 
Table 12. Validity Test Result

\begin{tabular}{|c|c|c|c|c|}
\hline No & Variable & $\begin{array}{l}\text { Statement } \\
\text { Item }\end{array}$ & $\begin{array}{c}\mathbf{R} \\
\text { calculates }\end{array}$ & Description \\
\hline 1 & Social Media Marketing & $\begin{array}{l}\text { X.1 } \\
\text { X.2 } \\
\text { X.3 } \\
\text { X.4 } \\
\text { X.5 } \\
\text { X.6 } \\
\text { X.7 } \\
\text { X.8 } \\
\text { X.9 } \\
\text { X.10 }\end{array}$ & $\begin{array}{l}0,583 \\
0,486 \\
0,685 \\
0,747 \\
0,682 \\
0,621 \\
0,824 \\
0,569 \\
0,691 \\
0,764\end{array}$ & $\begin{array}{c}\text { Valid } \\
\text { Valid } \\
\text { Valid } \\
\text { Valid } \\
\text { Valid } \\
\text { Valid } \\
\text { Valid } \\
\text { Valid } \\
\text { Valid } \\
\text { Valid }\end{array}$ \\
\hline 2 & Brand Awareness & $\begin{array}{l}\text { Z.1 } \\
\text { Z.2 } \\
\text { Z.3 } \\
\text { Z.4 } \\
\text { Z.5 } \\
\text { Z.6 } \\
\text { Z.7 } \\
\text { Z.8 }\end{array}$ & $\begin{array}{l}0,631 \\
0,849 \\
0,659 \\
0,860 \\
0,793 \\
0,846 \\
0,860 \\
0,783\end{array}$ & $\begin{array}{l}\text { Valid } \\
\text { Valid } \\
\text { Valid } \\
\text { Valid } \\
\text { Valid } \\
\text { Valid } \\
\text { Valid } \\
\text { Valid }\end{array}$ \\
\hline 3 & Purchase Decision & $\begin{array}{l}\text { Y.1 } \\
\text { Y.2 } \\
\text { Y.3 } \\
\text { Y.4 } \\
\text { Y.5 } \\
\text { Y.6 } \\
\text { Y.7 } \\
\text { Y. } 8 \\
\text { Y.9 } \\
\text { Y.10 }\end{array}$ & $\begin{array}{l}0,908 \\
0,715 \\
0,752 \\
0,887 \\
0,859 \\
0,820 \\
0,855 \\
0,897 \\
0,897 \\
0,757\end{array}$ & $\begin{array}{c}\text { Valid } \\
\text { Valid } \\
\text { Valid } \\
\text { Valid } \\
\text { Valid } \\
\text { Valid } \\
\text { Valid } \\
\text { Valid } \\
\text { Valid } \\
\text { Valid }\end{array}$ \\
\hline
\end{tabular}

Based on table 12., it shows that all items or statement items totaling 28 statements on each social media marketing variable, brand awareness, and purchasing decisions have an $r$ count that exceeds the $r$ table of 0.361 . Then the statement items on all research variables are said to meet the validity requirements and are declared valid and can be used as measuring instruments for this study.

\subsection{Reliability Test}

The following are the results of the reliability test for each variable, social media marketing, brand awareness, and purchasing decisions:

Tabel 13. Reliability Test Result

\begin{tabular}{|l|c|c|c|c|}
\hline Variable & $\begin{array}{c}\text { Number of } \\
\text { Statement }\end{array}$ & $\begin{array}{c}\text { Cronbach's } \\
\text { Alpha }\end{array}$ & $\begin{array}{c}\text { Minimum } \\
\text { Limit } \\
\text { Cronbach's } \\
\text { Alpha }\end{array}$ & Description \\
\hline $\begin{array}{l}\text { Social } \\
\text { Media } \\
\text { Marketing }\end{array}$ & 10 & .857 & 0.60 & Reliable \\
\hline $\begin{array}{l}\text { Brand } \\
\text { Awareness }\end{array}$ & 8 & .911 & 0.60 & Reliable \\
\hline $\begin{array}{l}\text { Purchase } \\
\text { Decision }\end{array}$ & 10 & .948 & 0.60 & Reliable \\
\hline
\end{tabular}

Table 13. shows that the results of the reliability test on the variables of social media marketing, brand awareness, and purchasing decisions have a Cronbach's Alpha value exceeding 0.60. Therefore the statement items from each variable are declared reliable or appropriate to be used for this study.

\subsection{Classic Assumption Test Normality Test}

In this study, normality testing using a statistical test with Kolmogorov-Sminorv technique uses an Exact Significant approach with the help of SPPS Statistic 25 measuring tools.

Table 14. Normality Test Result

\begin{tabular}{|l|c|c|}
\hline & $\begin{array}{c}\text { Kolmogorov-Smirnov } \\
\text { Exact Sig. (2-tailed) }\end{array}$ & $\begin{array}{c}\text { Unstandardized } \\
\text { Residual }\end{array}$ \\
\hline $\mathrm{N}$ & Struktur 1 & 100 \\
& Struktur 2 & 0,169 \\
& Source: Data Processed by Researches,2021 & 0,254 \\
\hline
\end{tabular}

Based on table 14. the results of the normality test on structure 1 and structure 2 can be seen through the residual value of the data which has a significant value of 0.169 for structure 1 and 0.254 for structure 2. The two values above have a value greater than alpha 0.05. Accordingly, this shows that the data used in this study is normally distributed.

\section{Multicollinearity test}

The following are the results of the multicollinearity test for each variable:

Table 15. Multicollinearity Test Result

\begin{tabular}{|c|c|c|c|}
\hline Equation & Model & Tolerance & VIF \\
\hline Model 1 & Social Media Marketing & 1,000 & 1,000 \\
& & & \\
Model 2 & Social Media Marketing & 0,520 & 1,925 \\
& Brand Awareness & 0,520 & 1,925 \\
\hline
\end{tabular}

Based on table 15. The results of the multicollinearity test show that the VIF value for the structure 11,000 is smaller than the VIF value 10 and the tolerance value 1,000 is greater than the tolerance value 0.10 . For structure 2, the VIF value of 1.925 is smaller than the VIF value of 10 and the tolerance value of 0.520 is greater than the tolerance value of 0.10 . Subsequently, it can be concluded that there is no multicollinearity in the two variables.

\section{Heteroscedasticity Test}

The following are the results of the heteroscedasticity test for each variable:

Tabel 16. Heteroscedasticity Test Result 


\begin{tabular}{|c|c|c|c|}
\hline $\begin{array}{l}\text { Structure } 1 \\
\end{array}$ & Social Media Marketing & $-0,890$ & 0,375 \\
\hline Structure 2 & $\begin{array}{l}\text { Social Media Marketing } \\
\text { Brand Awareness }\end{array}$ & $\begin{array}{l}-0,826 \\
-0,502\end{array}$ & $\begin{array}{l}0,411 \\
0,617\end{array}$ \\
\hline
\end{tabular}

Based on table 16, the results of the heteroscedasticity test show that the significant value for the structure of 1 social media marketing variable is 0.375 , which is greater than 0.05 . Then for the structure of the 2 social media marketing variables, 0.411 is greater than 0.05 and the brand awareness variable has a significant value of 0.617 , which is greater than 0.05 . It is said that in this study, the regression model did not experience heteroscedasticity.

\subsection{Path Analysis}

The structural equation in this study uses a simple path diagram model with three variables, the social media marketing variable $(\mathrm{X})$, the brand awareness variable $(\mathrm{Z})$, and the purchasing decision variable (Y). The formulation of the structural model can be seen as follows:

$$
\text { a. Model equation } 1 \quad \mathrm{Z}=\rho \mathrm{ZX}+e 1
$$

b. Model equation 2

$$
\mathrm{Y}=\rho \mathrm{YX}+\rho \mathrm{YZ}+\mathrm{e} 2
$$

Description:

$\rho=$ Path Coefficient

$\mathrm{e}=$ Residual Error

$\mathrm{X}=$ Independent Variable

$\mathrm{Z}=$ Variable Intervening

\begin{tabular}{|c|c|c|c|c|c|c|}
\hline \multirow{2}{*}{\multicolumn{2}{|c|}{ Model }} & \multicolumn{2}{|c|}{$\begin{array}{l}\text { Unstandardized } \\
\text { Coefficients }\end{array}$} & \multirow{2}{*}{$\begin{array}{c}\begin{array}{c}\text { Standardized } \\
\text { Coefficients }\end{array} \\
\text { Beta } \\
\end{array}$} & \multirow{3}{*}{$\begin{array}{c}\mathbf{t} \\
1,249 \\
\end{array}$} & \multirow{3}{*}{$\begin{array}{c}\text { Sig. } \\
0,215 \\
\end{array}$} \\
\hline & & B & Std.Error & & & \\
\hline \multirow[t]{2}{*}{1} & (Constant) & 3,609 & 2,891 & & & \\
\hline & $\begin{array}{l}\text { Social Media } \\
\text { Marketing }\end{array}$ & 0,667 & 0,070 & 0,693 & 9,520 & 0,000 \\
\hline \multicolumn{2}{|c|}{$\begin{array}{l}\text { R Square } \\
\text { F Statistic } \\
\text { Sig. Uji F }\end{array}$} & $\begin{array}{l}0,480 \\
90,632 \\
0,000 \\
\end{array}$ & & & & \\
\hline
\end{tabular}

$\mathrm{Y}=$ Dependent Variable

Table 17. Path Analysis Test Model 1 Result

Significance value of the social media marketing variable is 0.000 , which is less than 0.05 and the t-table value or the positive regression coefficient is 9.520 . These results can be concluded that H1: the social media marketing variable has a positive and significant effect on the brand awareness variable, is accepted.

The regression coefficient value of social media marketing has a value of 0.693 . The influence of the independent variable on the dependent variable can be seen from the total determination value ( $\mathrm{R}$ Square) of 0.480 or it means that $48 \%$ of the variation in the brand awareness variable is influenced by variations of social media marketing variables, while the remaining $52 \%$ comes from factors or variables that do not exist in this research model.

For more details regarding the flow of regression testing, it can be seen from the path diagram of the structural model I with the following equation:

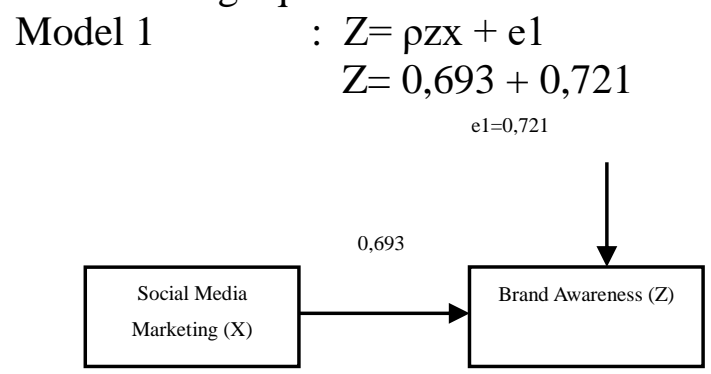

Figures 2. Path Diagram Model 1

\begin{tabular}{|c|c|c|c|c|c|c|}
\hline \multirow{2}{*}{\multicolumn{2}{|c|}{ Model }} & \multicolumn{2}{|c|}{$\begin{array}{c}\text { Unstandardized } \\
\text { Coefficients }\end{array}$} & \multirow{2}{*}{$\begin{array}{c}\begin{array}{c}\text { Standardized } \\
\text { Coefficients }\end{array} \\
\text { Beta } \\
\end{array}$} & \multirow[t]{2}{*}{$\mathrm{t}$} & \multirow[t]{2}{*}{ Sig. } \\
\hline & & B & Std.Error & & & \\
\hline \multirow[t]{3}{*}{1} & (Constant) & $-0,705$ & 3,647 & & $-0,193$ & 0,847 \\
\hline & $\begin{array}{l}\text { Social Media } \\
\text { Marketing }\end{array}$ & 0,464 & 0,122 & 0,354 & 3,815 & 0,000 \\
\hline & $\begin{array}{l}\text { Brand } \\
\text { Awareness }\end{array}$ & 0,630 & 0,126 & 0,463 & 4,986 & 0,000 \\
\hline \multicolumn{2}{|c|}{$\begin{array}{l}\text { R Square } \\
\text { F Statistik } \\
\text { Sig. Uji F }\end{array}$} & $\begin{array}{l}0,566 \\
63,313 \\
0,000\end{array}$ & & & & \\
\hline
\end{tabular}

Table 18. Regression Analysis Test Results of Structure Path 2

Significance value of the social media marketing variable is 0.000 , which is smaller than 0.05 and the table value or regression coefficient is positive at 3.815. These results can be concluded that H2: the social media marketing variable has a positive and significant effect on the purchasing decision variable, is accepted. Then the significance value of the brand awareness variable is 0.000 which is smaller than 0.05 and has a t table value or positive regression coefficient of 4.986 . These results can be concluded that H3: the brand awareness variable has a positive and 
significant effect on the purchasing decision variable, is accepted.

The regression coefficient value of social media marketing has a value of 0.354 . Then for the brand awareness variable has a regression coefficient value of 0.463 . The influence of the independent variable on the dependent variable can be seen from the total determination value ( $\mathrm{R}$ Square) of 0.566 or it means that $56.6 \%$ of the variation in purchasing decision variables is influenced by variations of social media marketing and brand awareness variables, while the remaining $43.4 \%$ comes from of factors or variables that do not exist in this research model.

For more details regarding the flow of regression testing, it can be seen from the path diagram of the structure model II with the following equation:

Model II

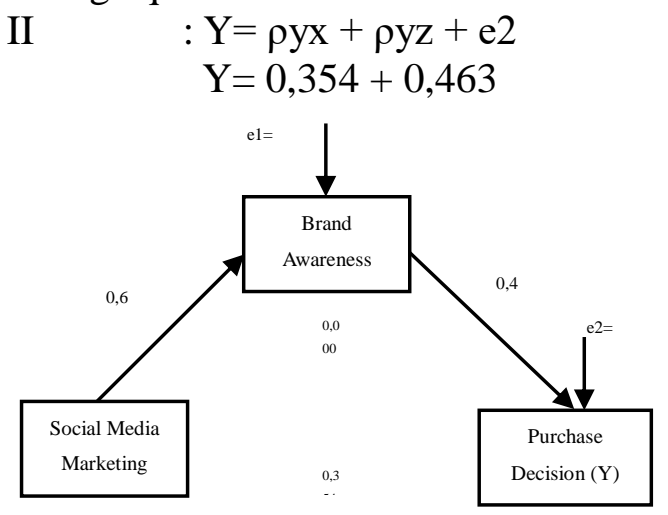

Figures 3. Path Diagram Model 2

Based on the path diagram in Pictures 3. the direct effect, indirect effect, and total effect of each research variable can be calculated for each value. An explanation of the calculation between variables can be seen from the following table:

Table 19. Direct Effect, Indirect Effect, and Total Effect of Social Media Marketing (X),

Brand Awareness (Z), and Purchase Decision $(\mathrm{Y})$

\begin{tabular}{|c|c|c|c|c|}
\hline No & $\begin{array}{c}\text { Effect } \\
\text { Variable }\end{array}$ & $\begin{array}{c}\text { Direct } \\
\text { Effect }\end{array}$ & $\begin{array}{c}\text { Indirect Effect } \\
\text { Brand through } \\
\text { Awareness } \\
(\mathbf{Y} 1)(\boldsymbol{\beta 1} \mathbf{x} \boldsymbol{\beta 3})\end{array}$ & Total Effect \\
\hline 1 & $\mathrm{X} \rightarrow \mathrm{Z}$ & 0,693 & - & 0,693 \\
\hline 2 & $\mathrm{X} \rightarrow \mathrm{Y}$ & 0,354 & 0,321 & 0,675 \\
\hline 3 & $\mathrm{Z} \rightarrow \mathrm{Y}$ & 0,463 & - & 0,463 \\
\hline \multicolumn{4}{|l}{} \\
Source: Data Processed by Researches,202I
\end{tabular}

Based on table 20. shows that the direct effect of social media marketing variables on brand awareness has a value of 0.693. The direct effect of social media marketing variables on purchasing decisions has a value of 0.354 and the indirect Influence given by the brand awareness variable is 0.321 . The influence of the brand awareness variable on the decision has a value of 0.463 . Thus, it can be said that the purchase decision variable is more influenced by the social media marketing variable through brand awareness because the total value given is 0.675 . Therefore, the total influence given by the social media marketing variable on the purchasing decision variable through the brand awareness variable is greater than the direct influence of the social media marketing variable on the purchasing decision variable without going through the brand awareness variable.

\subsection{Sobel Test}

The Sobel test is used to measure the mediation effect given by the intervening variable through testing the indirect effect of social media marketing $(\mathrm{X})$ on purchasing decisions $(\mathrm{Y})$ through the brand awareness (Z). If the value of $t$ count is greater than $t$ table of 1.984 with a $95 \%$ confidence level, then the mediating variable is declared capable of significantly mediating the relationship between the independent variable and the dependent variable. This can be known through the Sobel test formula, which is as follows:

$$
\mathrm{Sab}=\sqrt{b^{2} s a^{2}+a^{2} s b^{2}+s a^{2} s b^{2}}
$$

\section{Description:}

Sab : the standard error of indirect effect

b : independent variable path (x) with intervening variable $(\mathrm{z})$

b : intervening variable path $(\mathrm{z})$ with dependent variable (y

sa $\quad$ : standard error coefficient a

$\mathrm{sb}$ : $\quad$ standard error coefficient $b$

Based on the above formula, the results of the Sobel test calculation in this study are as follows:

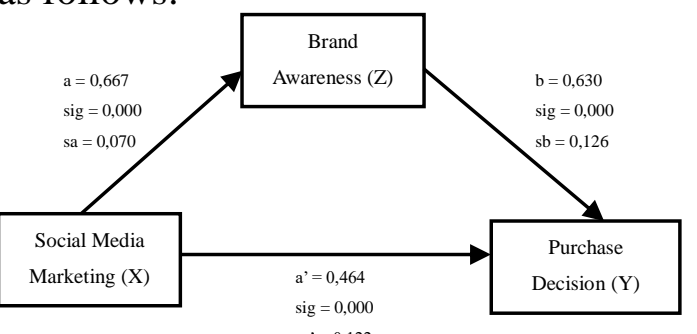


Figures 4. Sobel Test Regression Analysis Result

$\mathrm{Sab}$

$$
\begin{aligned}
& =\sqrt{b^{2} s a^{2}+a^{2} s b^{2}+s a^{2} s b^{2}} \\
& =\sqrt{0,630^{2} \cdot 0,070^{2}+0,667^{2} \cdot 0,126^{2}+0,070^{2} \cdot 0,126^{2}} \\
& =\sqrt{0,002+0,007+0,000} \\
& =\sqrt{0,009} \\
& =0,094
\end{aligned}
$$

The influence of the brand awareness variable as a mediating variable can be calculated by the $t$ value of the ab coefficient with the following formula:

$$
\begin{aligned}
\mathrm{t} & =\frac{\mathrm{ab}}{\mathrm{sab}} \\
& =\frac{0,667 \times 0,630}{0,094} \\
& =4,468
\end{aligned}
$$

Based on the above calculations, it can be concluded that the $t$-count value of 4.468 is greater than the t-table value of 1.984 . Hence, it can be concluded that there is an influence of mediation, and indirectly social media marketing through brand awareness has an influence on purchasing decisions. This can be interpreted as H4: Social media marketing has a positive and significant effect on purchasing decisions through brand awareness, is accepted.

The results of the analysis of data on the impact of social media marketing on purchasing decisions through brand awareness as a variable intervening in Praketa Coffee Shop Purwokerto, are the following:

\section{The influence of social media marketing on purchasing decisions}

In this study, respondents' knowledge of social media marketing at Praketa Coffee
Shop Purwokerto, overall has a good value with a value of 81.9. All categories in the descriptive analysis table are included in the good and very good categories. Therefore, it can be concluded that Praketa Coffee Shop Purwokerto is able to use and implement well the use of social media in every marketing activity.

Based on the results of the regression analysis of the influence of social media marketing on purchasing decisions, it is found that social media marketing has a positive and significant influence on purchasing decisions at Praketa Coffee Shop Purwokerto, so $\mathrm{H} 0$ is rejected and $\mathrm{H} 2$ is accepted. These results are obtained from the resulting significance value of 0.000 $<0.05$. Then the path coefficient value is positive at 0.354 . Accordingly, the results of this study can be concluded that the use of social media in Praketa Coffee Shop has an important role to improve consumer purchasing decisions. This means that the higher the use of social media marketing, the consumer's purchase decision making will increase. This is in accordance with previous research conducted by Upadana \& Pramudana (2020) which shows that social media marketing has a positive effect on purchase decisions, the better the level of social media marketing, the better the level of consumer purchasing decisions.

The influence of social media marketing on brand awareness

The results of the regression analysis of social media marketing on brand awareness showed that social media marketing had a positive and significant effect on brand awareness, so $\mathrm{H} 0$ was rejected and $\mathrm{H} 1$ was accepted. This can be seen from the results of the significance value of $0.000<0.05$ and has a positive path coefficient value of 0.693 Consequently the results of this study can be concluded that the use of social media marketing Praketa Coffee Shop has an important role in increasing consumer brand awareness. This means that the higher the use of social media as a marketing tool, the better the level of consumers in remembering the Praketa Coffee Shop 
Purwokerto brand. This is in accordance with previous research conducted by Sutariningsih (2021) that social media marketing has a positive and significant effect on brand awareness, the better and more attractive the marketing done through social media marketing, the better brand awareness-

\section{The influence of brand awareness on purchase decisions}

In this study, respondents' knowledge of brand awareness of Praketa Coffee Shop Purwokerto was included in the good category with a total score of $78.4 \%$. All categories in the descriptive analysis table are included in the good and very good categories. Therefore, it can be concluded that Praketa Coffee Shop Purwokerto is able to give a good impression so that consumers can remember their brand.

Based on the results of the regression analysis of the effect of brand awareness on purchasing decisions, it is found that brand awareness has a positive and significant influence on purchasing decisions, so $\mathrm{HO}$ is rejected and $\mathrm{H} 3$ is accepted. These results come from a significance value of 0.000 which has a value less than 0.005 , and has a path coefficient value of 0.463 . Hence, the results of this study can be concluded that building consumer brand awareness is very influential in the purchase decision-making process. This means that the better the brand awareness, the higher the decision to purchase Praketa Coffee Shop products. This is in line with previous research by Adhawiyah (2019) that brand awareness has a direct and significant effect on purchasing decisions.

\section{The influence of social media marketing on the formation of brand awareness and purchasing decisions}

Based on the results of the Sobel Test on brand awareness as an intervening or mediating variable, the resulting $\mathrm{t}$ value is greater than $t$ table. The value is $4,468>$ 1,984 , so these results indicate that brand awareness has a mediating effect on social media marketing relationships on purchasing decisions. The direct influence of social media marketing on purchase decisions is 0.354 , while the indirect influence is 0.321 after brand awareness is an intervening variable. Thus, the total influence of social media marketing on purchasing decisions through brand awareness is 0.675 . The results of the study indicate that $\mathrm{H} 0$ is rejected and $\mathrm{H} 4$ is accepted. It can be concluded that the stronger consumer brand awareness, it will have an impact on the intensity of social media marketing interactions so that consumers can be influenced to make purchases on Praketa Coffee Shop Purwokerto products. This result is in line with the research of Upadana and Pramudana, (2020) that brand awareness is able to mediate the influence of social media marketing on purchase decisions, the better the level of consumer awareness, the better the level of purchas decisions that occur.

\section{Conclusion}

Social media marketing has a positive and significant effect on brand awareness at Praketa Coffee Shop Purwokerto by 0.480 or $48 \%$ indicating that the influence comes from variations in social media marketing on brand awareness, while the remaining 0.520 or $52 \%$ is the amount of the contribution value of the variables which were not researched. This shows that the higher the use of social media as a marketing medium, the brand awareness or consumer awareness of the Praketa Coffee Shop brand will increase. Conversely, if the use of social media is getting lower or rarely applied, then brand awareness or consumer awareness of the brand will also decrease. This means that the existence of an ideal social media marketing, brand awareness consumer will be created by itself.

The social media marketing variable in this research has a low average value of $78.4 \%$ with the statement "Social Media Praketa Coffee gives interesting video posting". It shows that information through video content not yet reported through social media has not attracted consumer attention. To that end, Praketa Coffee Shop 
is expected to be able to provide more interesting content in every aspect of its social media.

The brand awareness variable in this research has an average value of $70.2 \%$ with the statement "Praketa Coffee becomes the first brand that appeared to me when I wanted to drink coffee or just hang out at the coffee shop." It shows that the brand awareness that Praketa Coffee Shop has created has not been sufficiently applied in the consumer's mind, because consumers have not yet been able to make Praketa Coffee Shop their top of mind. To that end, the Coffee Shop better enhance various kinds of promotions such as making more specific products, merchandise related to the Coffee Shop, so that consumers know more about brands or the Coffee Shop Practice identity.

Social media marketing has a positive and significant effect on purchasing decisions at Praketa Coffee Shop Purwokerto by 0.566 or $56 \%$ indicating that the influence comes from variations of social media marketing on purchasing decisions, while the remaining 0.434 or $43.4 \%$ is the amount of the contribution value of the unexamined variables. This shows that the higher the use of social media as a marketing medium, the decision-making process for purchasing Praketa Coffee Shop Purwokerto products will increase. Conversely, if the use of social media is getting lower or worse, the decision-making process for product purchases will decrease. This means that the existence of optimal social media marketing, the consumer decision-making process will be created on its own.

The purchasing decision variable in this study has the lowest average value of $69.6 \%$ with the statement "I am willing to always be loyal to Praketa Coffee". This shows that not all consumers are willing to always be loyal in buying products or hanging out at Praketa Coffee Shop. For this reason, Praketa Coffee Shop needs to increase promotions and give a good impression to consumers so that consumers can make decisions to buy products and can always be loyal and believe that Praketa Coffee Shop products are able to meet their needs.

Brand awareness has a positive and significant effect on consumer's purchase decisions at Praketa Coffee Shop Purwokerto by 0.566 or $56.6 \%$ indicating that the influence comes from variations in brand awareness on purchasing decisions, while the remaining 0.434 or $43.4 \%$ represents the contribution value of the unexamined variables. This shows that the better the consumer's brand awareness of a brand, the more the decision-making process to buy Praketa Coffee Shop products will increase. Conversely, if consumer brand awareness is low or bad, then the decision-making process for product purchases will also decrease. This means that there is an ideal brand awareness, the consumer decision-making process will be created on its own.

Brand awareness mediates positively and significantly on the relationship of social media marketing to purchasing decisions. These results can be shown by the Sobel test where the $t$ count value is 4,468 > the $t$ table value is 1,984 . This shows that the decision making process of purchasing Praketa Coffee Shop products is very dependent on the existence of brand awareness and social media marketing.

The perspective that according to consumers is not good, is expected to be evaluated by Praketa Coffee Shop so that problem solving can be done easily and find the best solution to improve purchasing decisions at Praketa Coffee Shop Purwokerto. Likewise, aspects that according to consumers are good, are expected to always be maintained and improved so that consumer assessments of purchasing decisions continue to increase.

\section{References}

Adhawiyah, Y. R., Anshori, M. I., \& As, F. (2019). Peran Pemasaran Media Sosial Dalam Menciptakan Keputusan Pembelian Melalui Kesadaran Merek 
(Studi pada Instagram Clothing Line Bangjo). Tirtayasa Ekonomika, 14(2), 267.

https://doi.org/10.35448/jte.v14i2.653

0

Ernawan, Y., Sudono, A., \& Sukirman, O. (1999). Evaluasi Penerapan Personal Selling Terhadap Keputusan Pembelian Menu Unpopular dan Profitable di Restoran Kampung Daun. 5.

Febriyan, F., \& Supriono. (2018). Pengaruh Pemasaran Media Sosial Terhadap Brand Awareness Pada Produk Internasional (Survei Pada Komunitas Xiaomi Indonesia). Jurnal Administrasi Bisnis, 61(1), 74-79.

Godey, B., Manthiou, A., Pederzoli, D., Rokka, J., Aiello, G., Donvito, R., \& Singh, R. (2016). Social media marketing efforts of luxury brands: Influence on brand equity and consumer behavior. Journal of Business Research, 69(12), 5833-5841. https://doi.org/10.1016/j.jbusres.2016. 04.181

Herdana, A. (2015). Analisis Pengaruh Kesadaran Merek (Brand Awareness) Pada Produk Asuransi Jiwa Prudential Life Assurance (Studi Pada Pru Passion Agency Jakarta). Jurnal Riset Bisnis Dan Manajemen, 3(1), 1-18.

Kuspriyono, T., \& Nurelasari, E. (2018). Pengaruh Social Media Marketing Terhadap Customer Bonding dan Purchase to Intention. Cakrawala, 18(2), 235-242. doi: https://doi.org/10.31294/jc.v18i2

Made Wahyu Krisna Upadana, \& Pramudana, K. A. S. (2020). Brand Awareness Memediasi Pengaruh Social Media Marketing Terhadap Keputusan Pembelian Made Wahyu Krisna Upadana 1 Fakultas Ekonomi dan Bisnis Universitas Udayana ( Unud ), Bali , Indonesian Abstrak Pendahuluan Manusia adalah makhluk sosial dimana setiap. Manajemen, E-Jurnal, 9(5), 1921-1941.

Poturak, M., \& Softić, S. (2019). Influence of Social Media Content on Consumer Purchase Intention: Mediation Effect of Brand Equity. Eurasian Journal of Business and Economics, 12(23), 17-43.

https://doi.org/10.17015/ejbe.2019.023 .02

Raharjo, S. T., \& Samuel, H. (2010). Pengaruh Social Media Marketing Terhadap Purchase Intention melalui Brand Awareness Sebagai Variabel Mediasi pada Lazada. 1-6.

Sara, F. M., Sara, F. M., Ningsih, C., Andari, R., Katering, M. I., Pendidikan, F., \& Pengetahuan, I. (2009). Pengaruh Physical Evidence terhadap Keputusan Pembelian Konsumen di Café Infinito Culinery Bandung. 3.

Shahid, Z., Hussain, T., \& AZafar, D. F. (2017). The Impact of Brand Awareness on The consumers' Purchase Inten. Journal of Marketing and Consumer Research, 33.

Siali, F., Jiayi, P., Shakur, M. M. A., \& Ya'Kob, S. A. (2016). Relationship Between Brand Equity \& Comsumer Purchase Decision: A Case Of An International Brand of Footwear. International Journal of Service Management and Sustainability, 1(1), 58-75.

Sutariningsih, N. M. A., \& K, I. G. N. J. A. W. (2021). Peran Brand Awareness Memediasi Pengaruh Social Media Marketing Terhadap Purchase Intention. E-Jurnal Manajemen, 10(2), 145-164.

Yapa, U. A. S. (2017). The Impact of Social Media on Brand Awareness (With Special Reference to Facebook Use in Fast Moving Consumer Goods in Sri Lanka). International Journal of Engineering and Management Research, 7(5), 262-272. www.ijemr.net

Zahid, M. A. A. dan Z. (2014). Role of social media marketing to enhance CRM and brand equity in terms of purchase intention. Asian Journal of Management Research, 4(3), 533-549. 